the price of this convenience is rapid inflation now and a load of unrequited debt for later.) So should the international monetary institutions provide loans to help developing countries out of immediate trouble? The United States has stoutly resisted this proposal, and rightly. In the long run, the cause of development itself would be undermined if the World Bank and the International Monetary Fund were saddled with loans that could never be repaid. The best solution is that the international institutions should stick to their rigorous practice of not lending on empty prospectuses but that they should also be better equipped to finance economically sound oil-substitution schemes in developing countries. The question of principle that remains to be hammered out is whether the developing countries will accept the terms on which such assistance is offered.

Policies and prejudices inimical to development are not, however, confined to the developing countries, whose strongest argument is that industrial states seeking to bolster up a declining domestic textile or footwear industry habitually make it harder for them to pull themselves up by their bootstraps. Yet the best hope for both industrial and developing states is that the division of labour between them will find its natural (and constantly changing) level. This, so far as it goes, is the only durable basis for the "new economic order" on which many developing countries have set their hearts. The snag, for both parties to such a deal, is that the objective of industrial self-sufficiency must be replaced by that of interdependence. The domestic political and economic problems arising from an understanding along these lines would be serious. But no purpose will be served by hiding from them. If, as agreed at Cancun last week, there are to be talks within the United Nations on "global" economic problems, it is essential that the difficulties should not be buried. For it is a continuing frustration that the potential benefits of available technology should be denied because of the unwillingness of normally overtalkative politicans to say what is on their minds.

\section{Three million jobless}

\section{The growing army of the British unemployed may one day have jobs again. But what? And how?}

With British unemployment now statistically indistinguishable from three million, or more than eleven per cent of the workforce, it is natural that the government should be nervous, the unemployed angry and those still with jobs both anxious and confused. The dole queues will be even longer by the time that the new Technical Change Centre has something to say on the subject which is central to its programme (see page 695). Already the rolls of the unemployed have been swollen by several thousand teachers from the schools, where demography of necessity strikes first. In the next few months, they will be further increased by some thousands of academics from higher education - some from the universities, some from the other institutions of higher education once the government has learned to cut them down to size. So what is to be made of it all?

The simplest and most comforting assumption is that the dole queues will shrink again when prosperity returns, whereupon people will go back to the jobs from which they have recently been displaced. But that implies that the upheavals of the past few years will have left no lasting mark on the pattern of British industry. The more disturbing but more realistic assumption is that the lists of the unemployed presage a lasting change similar in kind that required to strike an accommodation between the rich and poor countries (see above) but driven by the new technology whose seeds now abound (see Nature 15 October, p.499). Already, in Britain and the rest of Western Europe, steel-making capacity has been reduced and is unlikely ever again to be increased. If the demand for steel picks up, new plants elsewhere will be able to take up the slack more cheaply. The shift from manufacturing industry to service industries, the twentieth century equivalent of the previous century's drift from the land, will continue. In the years ahead, part but not all of the service sector will need fewer people to do the same work, with the result that during the recovery from the slump, it will be hard to tell whether people will be displaced more rapidly by automation from manufacturing industry than by administrative computers from the office. So how, it will be asked, is it possible to plan ahead?

The simple answer is that planning ahead is not possible at all: the future for jobs, in Britain or anywhere else, will depend on the success with which countries are able to compete in productivity. But one thing is clear. The valuable jobs will be jobs that require technical skill. Not merely will they reward those who do them more handsomely than other jobs, but they will contribute substantially to the wealth of the community. In an ideal world, the two components of the job queues - the teachers displaced from their jobs and the young people who all too often have tragically not had a chance to work - would pool their resources so as to make the best of this circumstance. The teachers would help the unskilled young people to become eligible for the kinds of jobs the future needs. They might even in the process decide to establish some kind of institution for the transfer of skill from the skilled to the unskilled jobless. They might even call it a university. If they did so, the Privy Council would probably be asked by the University Grants Committee to stop them.

So must not this be the worst time for the British government to cut back the budget for education? That is the obvious conclusion. Yet it is too obvious. For the British government has no choice but to save money across the board. Numerically, education has not done badly in recent years. The abruptness of the cut in the universities will harm institutions and scholarship principally because it is so abrupt - if the universities had been given say five years (not three) to live with 8.5 per cent less each year, and had been allowed to be flexible both in the pattern of their teaching and the means by which they recruited funds, few of them would have been able to complain. It is not, after all, as if the British educational system is above reproach. At all levels, it is academically too specialized, too snobbish (Oxbridge) and too slow to change. The complaint that academics should be making against the government is that it has not merely cut the public funds available but also settled the scale and pattern on which educational institutions will operate for years to come. Apparently persuaded that the educational system as it is could not cater for the future need of skill, it has neglected to ask whether a differently organized system might serve the purpose better. If it persists in this indifference, there is only a meagre chance that unemployment will shrink below three million.

The unemployed also have a complaint to make more subtle than that so far made on their behalf by the trades unions. If the present upheaval in British industry marks a permanent and structural change in the pattern of industry, those now unemployed (and their children) have a right to ask for a chance of preparing for the new regime. Although the present government has continued many of its predecessors' schemes for retraining people changing jobs, these opportunities are designed to produce traditional craftsmen, bricklayers and carpenters for example, not the kinds of skilled people likely to be needed in the years ahead. Similarly, the youth opportunities programme which services to keep more than half a million school leavers off the streets (and the unemployment roll) is more a device for allowing young people to learn at first hand what the now obsolete skills are used for than a preparation for the future. Is it too much to hope that the new Secretary of State for Employment, $\mathrm{Mr}$ Norman Tebbit, will recognize that this practice is absurd? What he must devise are ways of helping young people to be trained as computer programmers, as people who know what electronic equipment is like, as people who may, when the economy picks up, have to use numerically controlled machine tools. Several steps are needed. The costs of fees paid to educational institutions (private as well as public) should be deductible from a person's income before he pays tax. The public sector of the educational system should be made more flexible, able to take in people without formal academic qualifications, in the evenings. And the government itself should provide those in the dole queues with a more realistic account of what the future may be like. 